(C) 2019. This manuscript version is made available under the CC-BY-NC-ND 4.0 license http:// creativecommons.org/licenses/by-nc-nd/4.0/

\title{
New Innovations in Ionic Liquid-based Miniaturised Amperometric Gas Sensors
}

\author{
Debbie S. Silvester*
}

Address: Curtin Institute for Functional Molecules and Interfaces, School of Molecular and Life Sciences, Curtin
University, GPO Box U1987, Perth, 6845, WA, Australia.
*Corresponding author: Silvester, Debbie d.silvester-dean@curtin.edu.au.
Tel.: +61-08-9266-7148; Fax: +61-08-9266-2300

Issue title: Volume 15 Innovative Methods in Electrochemistry

\begin{abstract}
:
Gas detection is an essential part of everyday life; for some applications, using sensors for toxic and hazardous gases can literally mean the difference between life and death. In this mini-review, recent progress in amperometric gas sensing using miniaturised electrodes and devices is described. The focus is on the use of non-volatile room temperature ionic liquids (RTILs) as electrolytes, which possess inherent advantages such as wide electrochemical windows, high thermal and chemical stability, intrinsic conductivity and good solvating properties. Various different gases, electrodes and RTILs have been investigated in the strive towards new materials for improved gas sensors. The most recent developments using porous membrane electrodes, planar devices (e.g. screen-printed, thin-film, microarray and interdigitated electrodes), and the modification of these surfaces for improved sensitivity are described. RTILs have great potential to be used as electrolytes in amperometric gas sensors, with improved lifespan of the sensor in hot/dry environments and allowing miniaturisation of devices. However, it is clear that more understanding of their long-term operation and utility in real environments (e.g. background air, varying temperatures and humidity levels) is needed before their realisation in successful commercial devices.
\end{abstract}

\section{Keywords:}

Gas sensing; amperometric; ionic liquids; miniaturised devices; voltammetry; chronoamperometry; Clark cell 


\section{Introduction}

Gas detection is important in a wide range of fields, as highlighted in Figure 1a [1]. Many of these applications rely on the accurate determination and quantification of gases in the environment around the sensor. Among the various techniques employed for gas detection, the amperometric principle - the notion that gas concentration can be correlated with current - is popular due its high sensitivity, high selectivity, low-cost, wide detection range, and low power requirements [2]. The first amperometric gas sensor (AGS) was introduced by Leyland Clark and colleagues in 1953 [3], and many modern commercially-available AGSs are still based on variations of this design [2, 4]. Amperometric gas sensors typically comprise of a handheld battery-powered device (Figure 1b) housing one or more packaged sensor devices (e.g. Figure 1c). The user simply presses a button that applies a potential bias (depending on the target gas), and the current is converted into a quantitative display on the sensor. A schematic of the interior of a typical AGS is shown in Figure 1d, comprising of three electrodes (working, counter and reference) placed in contact through an electrolyte (usually a water/sulfuric acid mixture). These devices are extremely popular for many applications, but the lifetimes of these sensors are limited by the evaporation of the solvent, making them unsuitable for long term deployment in very hot and dry conditions. Therefore, there has been a drive towards low-volatility materials such as room temperature ionic liquids (RTILs), as replacement solvents.

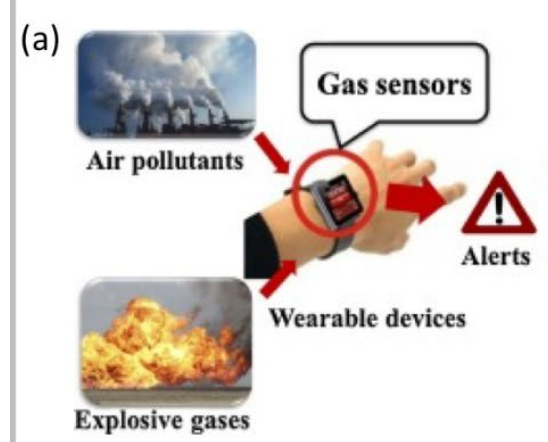

(b)

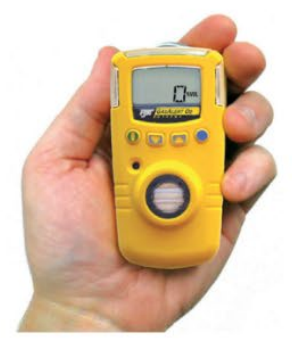

(c)

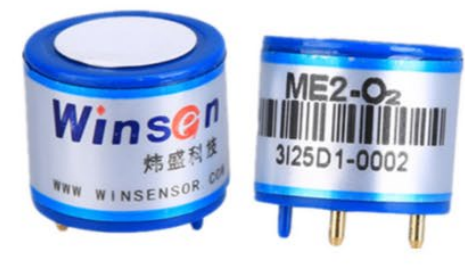

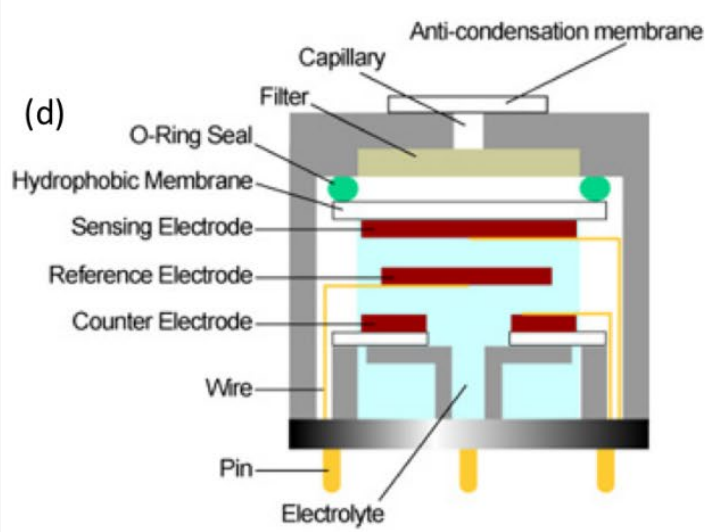

(e)

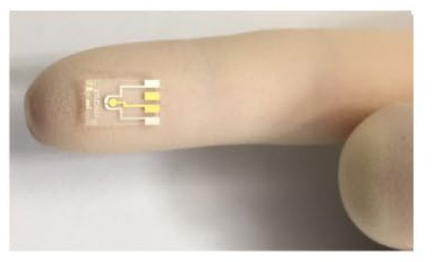

(f)

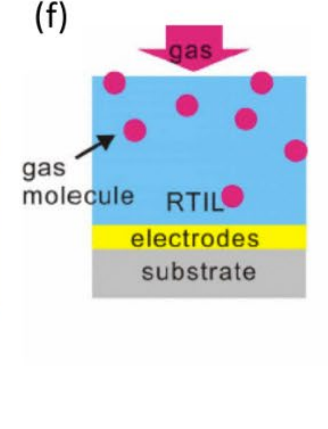

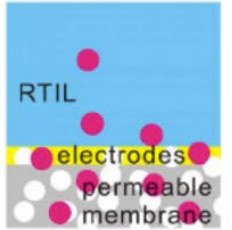

Figure 1. Overview of commercially available amperometric gas sensors and new miniaturised planar devices being used increasingly by academic researchers. (a) Applications of gas sensors deployed in wearable devices for real-time point-ofexposure gas monitoring, reproduced with permission from Elsevier from [1]. (b) Handheld device used for monitoring a single gas, from Dalton Engineering Ltd. (www.daltonengineering.co.uk). (c) Individual device(s) with gas-permeable membrane for monitoring $\mathrm{O}_{2}$ - three pins connect to the sensing electrode (WE), RE and CE (available from Winsen, www.winsensensor.com). (d) Schematic of the inside of a AGS, showing the electrodes, electrolyte, pins, seals and filter (membrane), from Membraphor www.membrapor.ch/electrochemical-gas-sensors. (e) Photo of a commercially available planar electrode device (thin-film electrode) from MicruX Technologies (www.micruxfluidic.com) showing the very small dimensions, adapted from [5] with permission from Elsevier. (f) Left: conventional sensor structure: response time is slow due to slow gas diffusion through RTIL. Right: electrodes-on-permeable-membrane structure: response time is improved due to fast gas diffusion in the permeable membrane, adapted from [6]. 
RTILs are salts with a melting point lower than room temperature $\left(25^{\circ} \mathrm{C}\right)$ and have several archetypal properties such as high chemical and thermal stability, low (near zero) volatility, intrinsic conductivity, wide electrochemical window, high viscosity, high polarity, good solvation properties and tunability [7]. The reader is directed to excellent review articles describing the general properties of RTILs as electrochemical solvents [8,9], and specifically their use in electrochemical sensors [10-14]. The concept of "membrane free" AGSs using RTILs was first introduced by Compton's group in 2004 [15], and the same group (and others) followed-up extensively with important research in the area [2,16,17], particularly to determine diffusion coefficients, solubilities and reaction mechanisms of gases in RTILs.

The removal of the membrane can add additional challenges such as solvent leakage, and the high viscosity of RTILs themselves can result in slow response times; various researchers have recently been working to overcome these challenges. In this mini-review, significant progress on RTIL-based AGSs since 2016 is discussed. It is not intended to be a comprehensive review of the area - interested readers are directed to other reviews devoted to RTIL-based gas sensors [2, 18-20], and in particular, the excellent technical review article by Gebicki et al. [21] that describes mechanism types of signal generation and an analysis of literature data for RTIL-based amperometric gas sensors up to 2016. This mini-review will discuss the authors' opinions on the future of the field and the challenges that lie ahead. A summary of the area is given in Figure 1, which compares commercially available AGS devices with miniaturised devices currently gaining attention in academic research. There appears to be a move away from conventional electrochemical devices with large volumes (e.g. several $\mathrm{mLs}$ ) of solvent, towards miniaturized designs that require less than $\sim 50 \mu \mathrm{L}$ of non-volatile RTILs.

\section{Amperometric Gas Sensing with Ionic Liquid Electrolytes}

Table 1 presents an overview of various amperometric (or voltammetric) methods used to detect gases since 2016, with details on the working (sensing) electrodes, ionic liquids, electrochemical techniques, and concentration ranges studied. It is not the intention here to compare sensitivities and limits of detection the focus will be primarily on the materials and methods used. In table 1, it is clear that a large majority of publications are focused on oxygen as an analyte gas; other gases such as hydrogen, or toxic gases such as ammonia, hydrogen chloride, sulfur dioxide, etc. are also studied. The next sections will highlight various approaches that researchers have used to incorporate RTILs in sensor devices, and innovative ways in which researchers have tried to improve their operation and overcome some of the challenges of membrane-free gas sensors. 
Table 1. Overview of the most significant research on amperometric gas sensing using RTIL solvents.

\begin{tabular}{|c|c|c|c|c|c|c|}
\hline Gas(es) & RTIL(s) & Electrode & $\begin{array}{l}\text { Conc. } \\
\text { studied }\end{array}$ & $\begin{array}{l}\text { Techniqu } \\
\text { e(s) used }\end{array}$ & Comments & $\begin{array}{l}{[\text { Ref[ }} \\
\text { Year }\end{array}$ \\
\hline $\begin{array}{l}\text { VOC in } \\
\text { air }\end{array}$ & {$\left[\mathrm{C}_{4} \mathrm{mpyrr}\right]\left[\mathrm{NTf}_{2}\right]$} & $\begin{array}{l}\text { Clark-type } \\
\text { sensor with } \\
\text { polycrystalline } \\
\text { Pt gauze. }\end{array}$ & $\begin{array}{l}\text { 200-3000 } \\
\text { ppm } \\
\text { (acetaldehyde) }\end{array}$ & $\begin{array}{l}\mathrm{CV} \text {, single, } \\
\text { double and } \\
\text { triple } \\
\text { potential- } \\
\text { step CA }\end{array}$ & $\begin{array}{l}\text { Platinum gauze WE in Clark-type cell with } \\
150 \mu \mathrm{L} \text { RTIL used. Acetaldehyde (a VOC) } \\
\text { could be indirectly determined by reaction } \\
\text { with electrogenerated superoxide from } \\
\text { reduction of oxygen in air, or trace water. } \\
\text { Double potential-step amperometry was } \\
\text { used after evaluation of coupled reaction } \\
\text { mechanisms. }\end{array}$ & $\begin{array}{l}{[22]} \\
2016\end{array}$ \\
\hline $\mathrm{O}_{2}$ & {$\left[\mathrm{C}_{4} \mathrm{mpyrr}\right]\left[\mathrm{NTf}_{2}\right]$} & $\begin{array}{l}\text { Clark-type } \\
\text { sensor with } \\
\text { polycrystalline } \\
\text { Pt gauze. }\end{array}$ & $1-20 \%$ & CV, LTCA & $\begin{array}{l}\text { Platinum gauze WE decorated with Pd } \\
\text { nanocrystals in Clark-type cell with } 150 \\
\mu \mathrm{L} \text { RTIL used. Presence of different facets } \\
\text { of Pd has little effect on oxygen reduction, } \\
\text { but significantly affects superoxide } \\
\text { oxidation. Better sensitivity and lower } \\
\text { LOD compared to Pt gauze. }\end{array}$ & $\begin{array}{l}{[23]} \\
2016\end{array}$ \\
\hline $\mathrm{H}_{2}$ & {$\left[\mathrm{C}_{4} \mathrm{mim}\right] \mathrm{Cl}$} & $\begin{array}{l}\text { Pd deposited on } \\
\text { carbon gas } \\
\text { diffusion } \\
\text { electrode. }\end{array}$ & $1-5 \%$ & CV, LTCA & $\begin{array}{l}\text { Fuel-cell based amperometric sensor with } \\
\text { Nafion as proton conducting electrolyte. } \\
\text { Better adhesion of Pd when deposited } \\
\text { from an ionic liquid. Sensor exhibited } \\
\text { excellent sensing response despite low } \\
\text { catalyst loading. }\end{array}$ & $\begin{array}{l}{[24]} \\
2017\end{array}$ \\
\hline $\mathrm{O}_{2}$ & {$\left[\mathrm{C}_{4} \mathrm{mpyrr}\right]\left[\mathrm{NTf}_{2}\right]$} & $\begin{array}{l}\text { Clark-type } \\
\text { sensor with } \\
\text { polycrystalline } \\
\text { Pt gauze. }\end{array}$ & $5-20 \%$ & $\begin{array}{l}\text { Single and } \\
\text { double } \\
\text { potential- } \\
\text { step CA, } \\
\text { LTCA }\end{array}$ & $\begin{array}{l}\text { Platinum gauze WE in Clark-type cell. } \\
\text { Sensor signal drift was characterised to } \\
\text { identify the contributing factors. Double } \\
\text { potential step chronoamperometry used to } \\
\text { reduce drift and extend sensor operating } \\
\text { lifetime. }\end{array}$ & $\begin{array}{l}{[25]} \\
2018\end{array}$ \\
\hline $\mathrm{H}_{2}$ & $\begin{array}{l}{\left[\mathrm{C}_{4} \mathrm{mim}\right]\left[\mathrm{NTf}_{2}\right],} \\
{\left[\mathrm{C}_{4} \mathrm{mpyrr}\right]\left[\mathrm{NTf}_{2}\right]}\end{array}$ & $\begin{array}{l}\text { Clark-type } \\
\text { sensor with } \\
\text { polycrystalline } \\
\text { Pt gauze. }\end{array}$ & $0.05-1.25 \%$ & CV, LTCA & $\begin{array}{l}\text { Porous Teflon membrane in contact with } \\
\text { Pt gauze WE. } 150 \mu \mathrm{L} \text { RTIL employed. } \\
\text { Low concentration range studied with best } \\
\text { results at a sampling time of } 20 \text { seconds. } \\
\text { Electrogenerated proton diffuses quickly } \\
\text { into the bulk RTIL, minimising signal } \\
\text { drift. Good selectivity for } \mathrm{H}_{2} \text { over } \\
\text { interferent VOC gases. }\end{array}$ & $\begin{array}{l}26] \\
2018\end{array}$ \\
\hline $\mathrm{O}_{2}$ & {$\left[\mathrm{C}_{4} \mathrm{mpyrr}\right]\left[\mathrm{NTf}_{2}\right]$} & $\begin{array}{l}\text { Pt on porous } \\
\text { PTFE substrate }\end{array}$ & $5.25-21 \%$ & CA, LTCA & $\begin{array}{l}\text { Microfabricated WE, CE and RE (Pt//Ti) } \\
\text { on planar porous PTFE substrate. Good } \\
\text { sensitivity, linearity and repeatability for } \\
\text { oxygen sensing. Methane-oxygen } \\
\text { electrochemical coupling method used to } \\
\text { detect methane. }\end{array}$ & $\begin{array}{l}{[27]} \\
2016\end{array}$ \\
\hline $\mathrm{O}_{2}$ (air) & {$\left[\mathrm{C}_{4} \mathrm{mpyrr}\right]\left[\mathrm{NTf}_{2}\right]$} & $\begin{array}{l}\text { Au on porous } \\
\text { PTFE substrate }\end{array}$ & $\sim 5-20 \%$ & $\begin{array}{l}\text { CV, single } \\
\text { and double } \\
\text { potential- } \\
\text { step CA, } \\
\text { LTCA }\end{array}$ & $\begin{array}{l}\text { Microfabricated WE, CE and RE }(\mathrm{Au} / / \mathrm{Ti}) \\
\text { on planar porous PTFE substrate. Double } \\
\text { potential amperometry used as a } \\
\text { favourable technique to reduce by-product } \\
\text { accumulation. }\end{array}$ & $\begin{array}{l}28] \\
2017\end{array}$ \\
\hline $\begin{array}{l}\mathrm{O}_{2}, \mathrm{CH}_{4}, \\
\mathrm{SO}_{2}, \mathrm{O}_{3}\end{array}$ & {$\left[\mathrm{C}_{4} \mathrm{mpyrr}\right]\left[\mathrm{NTf}_{2}\right]$} & $\begin{array}{l}\text { Pt on porous } \\
\text { PTFE substrate }\end{array}$ & $\begin{array}{l}5-20 \%\left(\mathrm{O}_{2}\right) \\
2-10 \%\left(\mathrm{CH}_{4}\right) \\
833-2500 \\
\operatorname{ppm}\left(\mathrm{SO}_{2}\right), 2- \\
10 \mathrm{ppm}\left(\mathrm{O}_{3}\right)\end{array}$ & $\mathrm{CA}$ & $\begin{array}{l}\text { Microfabricated WE, CE and RE }(\mathrm{Pt} / / \mathrm{Ti}) \\
\text { on planar porous PTFE substrate. Fast } \\
\text { response times, with good sensitivity, } \\
\text { linearity and repeatability. Various } \\
\text { different gases could be detected using } \\
\text { chronoamperometry. }\end{array}$ & $\begin{array}{c}1] \\
2018\end{array}$ \\
\hline
\end{tabular}




\begin{tabular}{|c|c|c|c|c|c|c|}
\hline $\mathrm{O}_{2}$ & $\begin{array}{l}{\left[\mathrm{C}_{2} \mathrm{mim}\right]\left[\mathrm{NTf}_{2}\right],} \\
{\left[\mathrm{C}_{4} \mathrm{mim}\right]\left[\mathrm{PF}_{6}\right]}\end{array}$ & SPE (graphite) & $\begin{array}{l}0.1-20 \% \text { and } \\
100 \%\end{array}$ & CV, LTCA & $\begin{array}{l}\text { Planar device with } 2-30 \mu \mathrm{L} \text {. Six RTILs } \\
\text { studied, with detailed analytical studies on } \\
\text { two RTILs. Not all SPE ink formulations } \\
\text { are compatible with RTILs for long-term } \\
\text { electrochemical experiments. Choice of } \\
\text { RTIL is also important for long-term } \\
\text { experiments. }\end{array}$ & $\begin{array}{l}{[29]} \\
2017\end{array}$ \\
\hline $\mathrm{O}_{2}$ & $\begin{array}{l}{\left[\mathrm{C}_{2} \mathrm{mim}\right]\left[\mathrm{NTf}_{2}\right],} \\
{\left[\mathrm{C}_{4} \mathrm{mpyrr}\right]\left[\mathrm{NTf}_{2}\right]}\end{array}$ & SPE (platinum) & $\begin{array}{l}10-100 \% \text { and } \\
0.1-5 \%\end{array}$ & CV, LTCA & $\begin{array}{l}\text { Planar device with } 30 \mu \text { LTIL. Unstable } \\
\text { behaviour towards } \mathrm{O}_{2} \text { reduction in } \\
{\left[\mathrm{C}_{2} \text { mim }\right]\left[\mathrm{NTf}_{2}\right] \text {, which improved upon }} \\
\text { mechanical polishing. }\end{array}$ & $\begin{array}{l}{[30]} \\
2016\end{array}$ \\
\hline $\mathrm{NH}_{3}$ & {$\left[\mathrm{C}_{2} \mathrm{mim}\right]\left[\mathrm{NTf}_{2}\right]$} & $\begin{array}{l}\text { SPE, TFE, } \\
\text { MATFE, } \\
\text { microdisk (all } \\
\text { Pt) }\end{array}$ & $\begin{array}{l}0.1-2 \mathrm{ppm} \\
\text { and } 10-100 \\
\text { ppm }\end{array}$ & LSV, CA & $\begin{array}{l}\text { Planar devices with } 2 \text { or } 8 \mu \mathrm{L} \text { RTIL. } \\
\text { Current density for ammonia oxidation } \\
\text { reported for planar devices and } \\
\text { conventional electrodes. Improved } \\
\text { sensitivity towards when recessed micro- } \\
\text { holes were filled with Pt. Lowest LOD } \\
\text { reported for ammonia, to date. }\end{array}$ & $\begin{array}{l}{[31]} \\
2016\end{array}$ \\
\hline $\mathrm{NH}_{3}$ & {$\left[\mathrm{C}_{2} \mathrm{mim}\right]\left[\mathrm{NTf}_{2}\right]$} & $\begin{array}{l}\text { SPE, TFE, } \\
\text { MATFE, } \\
\text { microdisk (all } \\
\text { Pt) }\end{array}$ & $10-100 \mathrm{ppm}$ & $\begin{array}{l}\text { LSV, } \\
\text { SWV, } \\
\text { DPV }\end{array}$ & $\begin{array}{l}\text { Three voltametric techniques compared - } \\
\text { LSV, SWV and DPV. LSV gave the } \\
\text { highest currents. Biggest difference on } \\
\text { micron sized electrodes. } 2,8 \text { and } 25 \mu \mathrm{L} \\
\text { RTIL used. }\end{array}$ & $\begin{array}{l}{[32]} \\
2018\end{array}$ \\
\hline $\mathrm{O}_{2}$ & {$\left[\mathrm{C}_{4} \mathrm{mpyrr}\right]\left[\mathrm{NTf}_{2}\right]$} & $\begin{array}{l}\text { Interdigitated } \\
\text { electrode }\end{array}$ & $\begin{array}{l}1400-4800 \\
\text { ppm }\end{array}$ & CV, LTCA & $\begin{array}{l}\text { Miniaturised interdigitated } \\
\text { microelectrodes detecting analytes with } \\
\text { reversible redox activity. Product at WE1 } \\
\text { (i.e. superoxide) is reoxidised at WE2. Can } \\
\text { provide selectivity over gases with } \\
\text { irreversible redox chemistry. } 1 \mu \mathrm{L} \text { RTIL } \\
\text { used on planar device. }\end{array}$ & $\begin{array}{l}{[33]} \\
2018\end{array}$ \\
\hline $\mathrm{O}_{2}$ & {$\left[\mathrm{C}_{2} \operatorname{mim}\right]\left[\mathrm{NTf}_{2}\right]$} & $\begin{array}{l}\text { Pt microdisk, Pt } \\
\text { MATFE }\end{array}$ & $0.1-100 \%$ & CV, LTCA & $\begin{array}{l}\text { RTIL mechanically stabilised by PMMA } \\
\text { to create a gel-polymer electrolyte on } \\
\text { planar device. Low currents with } \\
\text { MATFE/viscous GPE caused less } \\
\text { degradation after long-term experiments } \\
\text { compared to neat RTIL. } 5 \mu \mathrm{L} \text { used on } \\
\text { planar device. }\end{array}$ & $\begin{array}{l}{[34]} \\
2016\end{array}$ \\
\hline $\mathrm{O}_{2}$ & $\begin{array}{l}{\left[\mathrm{C}_{4} \mathrm{mim}\right]\left[\mathrm{PF}_{6}\right] \text {, }} \\
{\left[\mathrm{C}_{2} \mathrm{mim}\right]\left[\mathrm{PF}_{6}\right] \text { and }} \\
{\left[\mathrm{C}_{5} \mathrm{mim}\right]\left[\mathrm{PF}_{6}\right]}\end{array}$ & $\begin{array}{l}\text { Pt interdigitated } \\
\text { electrode }\end{array}$ & $0-100 \%$ & $\begin{array}{l}\text { CV, CA, } \\
\text { EIS }\end{array}$ & $\begin{array}{l}\text { RTIL mixed with Pt-modified ordered } \\
\text { mesoporous carbons, preventing } \\
\text { aggregation and providing a large number } \\
\text { of active sites for oxygen } \\
\text { reduction. Solid/gelled materials overcame } \\
\text { the leakage problem of RTILs. } \sim 20 \mu \mathrm{L} \\
\text { RTIL used on planar device. }\end{array}$ & $\begin{array}{c}{[35]} \\
2018\end{array}$ \\
\hline $\mathrm{O}_{2}$ & {$\left[\mathrm{C}_{4} \mathrm{mim}\right]\left[\mathrm{BF}_{4}\right]$} & $\begin{array}{l}\text { Home-made } \\
\text { planar electrode. } \\
\text { Pt WE (radius } \\
0.5 \mathrm{~mm}) . \mathrm{Pt} \mathrm{CE} \\
\text { and Pt RE ( } 0.5 \\
\text { mm diameter). }\end{array}$ & $20-100 \%$ & $\begin{array}{l}\text { CV, CA, } \\
\text { LTCA, } \\
\text { EIS }\end{array}$ & $\begin{array}{l}\text { RTIL combined with polymers to create } \\
\text { robust microporous films with enhanced } \\
\text { electrical properties. Double film } \\
\text { (PVDF/IL and PMMA/IL) on planar } \\
\text { substrate enhances electrochemical oxygen } \\
\text { sensor performance. } 5 \times 5 \mathrm{~mm} \text { films used. }\end{array}$ & $\begin{array}{l}{[36]} \\
2018\end{array}$ \\
\hline $\mathrm{O}_{2}$ & $\begin{array}{l}{[\mathrm{MOMIM}]\left[\mathrm{PF}_{6}\right]} \\
\text { (thiol- } \\
\text { functionalised } \\
\text { RTIL) }\end{array}$ & $\begin{array}{l}\mathrm{Au} \\
\text { microchannel } \\
\text { electrode }\end{array}$ & $\begin{array}{l}\text { 5000-25000 } \\
\text { ppm }\end{array}$ & CV, LTCA & $\begin{array}{l}\text { Thiol-functionalised ionic liquid used to } \\
\text { create microchannel arrays for robust } \\
\text { oxygen sensing, with no flow observed } \\
\text { when the electrode was placed in different } \\
\text { orientations. } \sim 1 \mu \mathrm{L} \text { RTIL used on planar } \\
\text { device. }\end{array}$ & $\begin{array}{c}{[37]} \\
2016\end{array}$ \\
\hline
\end{tabular}




\begin{tabular}{|c|c|c|c|c|c|c|}
\hline $\mathrm{O}_{2}$ & {$\left[\mathrm{C}_{4} \mathrm{mpyrr}\right]\left[\mathrm{NTf}_{2}\right]$} & $\begin{array}{l}\mathrm{Au} \\
\text { microchannel } \\
\text { electrode }\end{array}$ & $\begin{array}{l}500-400 \text { ppm } \\
\& 2000-5000 \\
\text { ppm }\end{array}$ & CV, LTCA & $\begin{array}{l}\text { RTILs impregnated with magnetic } \\
\text { nanostirrers }\left(\mathrm{CoFe}_{2} \mathrm{O}_{4} \text { nanoparticles) }\right. \\
\text { showed increased sensitivity towards } \\
\text { oxygen in a rotating magnetic field ( } 400 \\
\text { rpm). Response times also improved. } \sim 1 \\
\mu \mathrm{L} \text { RTIL used on planar device. }\end{array}$ & $\begin{array}{l}{[38]} \\
2017\end{array}$ \\
\hline $\begin{array}{l}\mathrm{NH}_{3}, \\
\mathrm{HCl}\end{array}$ & $\begin{array}{l}{\left[\mathrm{C}_{2} \operatorname{mim}\right]\left[\mathrm{NTf}_{2}\right],} \\
{\left[\mathrm{C}_{4} \mathrm{mpyrr}\right]\left[\mathrm{NTf}_{2}\right]}\end{array}$ & $\begin{array}{l}\mathrm{Au} \\
\text { microchannel } \\
\text { electrode }\end{array}$ & 20-100 ppm & $\begin{array}{l}\text { LSV, } \\
\text { LTCA }\end{array}$ & $\begin{array}{l}\text { Microchannel coated gold electrode with } \\
\sim 9 \mathrm{~nL} \text { RTIL. Highly sensitive and fast } \\
\text { detection of toxic gases. LODs } 3.6 \mathrm{ppm} \\
\left(\mathrm{NH}_{3}\right) \text { and } 3.7 \text { ppm }(\mathrm{HCl}) \text {, well below } \\
\text { long-term exposure limits. }\end{array}$ & $\begin{array}{l}{[39]} \\
2018\end{array}$ \\
\hline $\mathrm{NH}_{3}$ & {$\left[\mathrm{C}_{2} \operatorname{mim}\right]\left[\mathrm{NTf}_{2}\right]$} & $\begin{array}{l}\text { Pt MATFE, } \\
\text { Modified } \\
\text { MATFE }\end{array}$ & $10-100 \mathrm{ppm}$ & $\begin{array}{l}\text { LSV, } \\
\text { LTCA }\end{array}$ & $\begin{array}{l}\text { Recessed MATFEs modified by } \\
\text { electrodeposition of Pt 'cauliflower' } 3 \mathrm{D} \\
\text { structures. Enhanced sensitivity towards } \\
\text { ammonia oxidation }(7 \text { to } 12 \times) .2 \mu \mathrm{L} \text { RTIL } \\
\text { used on planar device. }\end{array}$ & $\begin{array}{l}{[40]} \\
2018\end{array}$ \\
\hline $\mathrm{O}_{2}$ & {$\left[\mathrm{~N}_{8,2,2,2}\right]\left[\mathrm{NTf}_{2}\right]$} & $\begin{array}{l}\text { Pt MATFE, } \\
\text { Modified } \\
\text { MATFE }\end{array}$ & $10-100 \%$ & $\mathrm{CV}$ & $\begin{array}{l}\text { MATFEs with Pt 3D structures, deposited } \\
\text { in one-step and two steps, in the } \\
\text { absence/presence of lead acetate to create } \\
\text { dendritic structures with high surface } \\
\text { areas. } 16 \text { times enhanced current. } 3 \mu \mathrm{L} \\
\text { RTIL used on planar device. }\end{array}$ & $\begin{array}{l}{[41]} \\
2018\end{array}$ \\
\hline $\mathrm{H}_{2}$ & {$\left[\mathrm{C}_{2} \mathrm{mim}\right]\left[\mathrm{NTf}_{2}\right]$} & $\begin{array}{l}\mathrm{Pt} \text {, Porous Pt, } \\
\mathrm{GC}\end{array}$ & $10-100 \%$ & CV, LTCA & $\begin{array}{l}\text { Macroporous Pt electrode created using } \\
\text { polystyrene spheres as a template on GC } \\
\text { and Pt electrodes. Thin-layer } \\
\text { characteristics in the CV with hydrogen } \\
\text { remaining in the pores. 'Leak detector' } \\
\text { application suggested. } 300 \mu \mathrm{L} \text { RTIL used. }\end{array}$ & $\begin{array}{l}{[42]} \\
2018\end{array}$ \\
\hline $\mathrm{H}_{2}$ & {$\left[\mathrm{C}_{2} \operatorname{mim}\right]\left[\mathrm{NTf}_{2}\right]$} & $\begin{array}{l}\mathrm{Pt}, \mathrm{Au} \text { and } \mathrm{Au} \\
\text { microchannel } \\
\text { electrodes, both } \\
\text { modified with } \\
\text { Pt nanoparticles }\end{array}$ & $10-100 \%$ & CV, LTCA & $\begin{array}{l}\text { Microchannel array gold electrode with } \sim 9 \\
\text { nL RTIL. Hydrogen electroactivity } \\
\text { achieved by depositing Pt nanoparticles } \\
\text { into the channels. Thin-layer behaviour } \\
\text { observed, and a very fast response }(<2 \mathrm{~s}) \\
\text { to } \mathrm{H}_{2} \text { concentration changes, due to the } \\
\text { presence of microchannels. }\end{array}$ & $\begin{array}{l}{[43]} \\
2019\end{array}$ \\
\hline
\end{tabular}

Note: Abbreviations are given at the end of the review.

\section{Porous Working Electrodes Based on the Conventional Clark-Cell Design}

Various groups have used home-made or commercial packaged devices based on the Clark-cell design (see Figure 1d), similar to those presently marketed to end-users. These have the significant advantage that the manufacturing process of the sensor device is well-established, all electrodes and electrolytes are wellcontained, and these devices may fill the space that is already available for existing sensors. A big benefit of this design is that the gas enters the cell through a porous working electrode (Figure 1f, right), avoiding the (often slow) partitioning/diffusion of gas through a thick layer of RTIL to the electrode (Figure 1f, left), improving response times. However, drawbacks include the more complicated manufacture of the sensor, in addition to possible water adsorption into the RTIL if no membrane is present; this can cause RTIL expansion within the tightly packaged design, which can cause damage to the sensor housing and leakage under high humidity environments. There is also limited potential for miniaturisation of this design, often requiring at least $100-150 \mu \mathrm{L}$ of RTIL solvent to connect the three electrodes, which can add to the overall cost of a sensor device due to the cost of RTILs. As a rough guide, commonly used RTILs for gas sensing applications are currently ca. 170-230 EUROs for $100 \mathrm{~mL}$. 
Among the various Clark-cell type designs, some highlights include the detection of oxygen [22, 23, 25] and hydrogen $[24,26]$ gases. Figure 2 shows a schematic of a sensor device used for detecting hydrogen gas with fast response times; hydrogen flows into the cell, where it diffuses through a gas-permeable membrane to the sensing electrode and is oxidised. Figure $2 b$ shows the calibration graphs of current vs concentration of $\mathrm{H}_{2}$, which show different sensitivities when the RTIL cation is changed. Figure 2c shows a real-time amperometric response (long-term chronoamperometry transient) for low concentrations of hydrogen (0.05-1.25\%) in the two RTILs, with a nitrogen purging step between each concentration change. Excellent reproducible signals are observed, with ascending and descending concentration currents almost identical. The issue of signal drift for a continuous "real-time" sensor was also discussed by the same group [25] in the context of oxygen detection.

As shown in Table 1, many of the sensing electrodes in this design are made of polycrystalline Pt gauze material, but some have been intentionally decorated with Pt nanocrystals for improved responses towards the analyte $[23,24]$. In general, the porous electrode design shows great promise for gas detection with fast response times and good long-term operation, but the requirement for high volumes of RTIL and complex packaging may raise the cost of a sensing platform for use in the field.

(a)

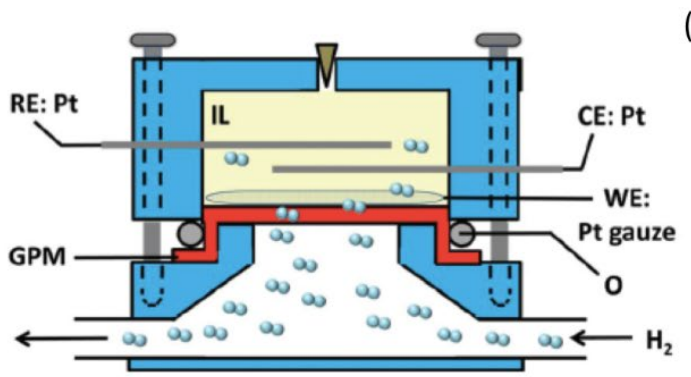

(c)

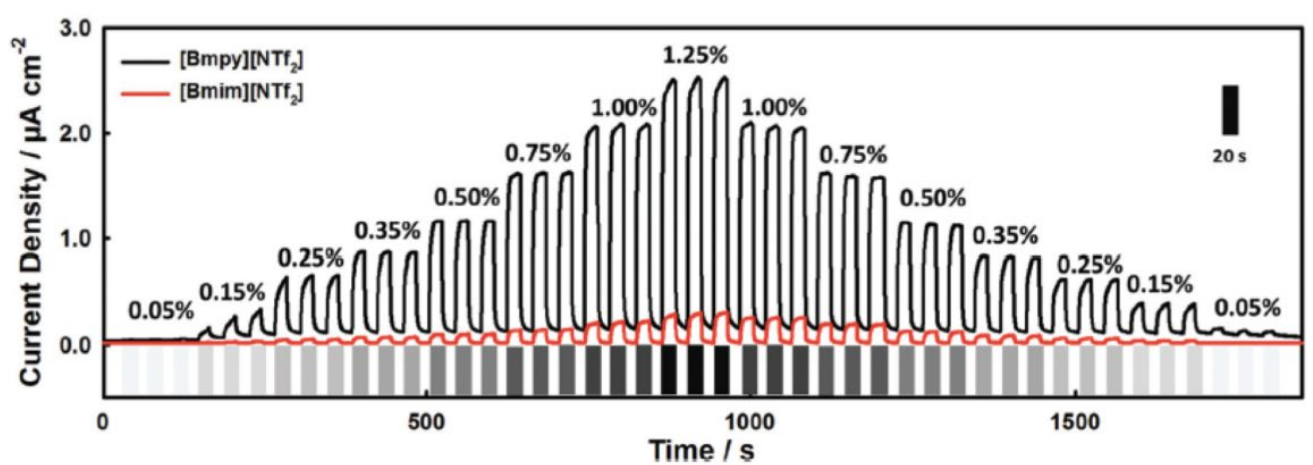

Figure 2. (a) Schematic diagram of Clark-type hydrogen sensor cell. Abbreviations are defined at the end of the review. (b) Calibration curves for concentration step up and down in two RTIL-based sensors at 20 seconds exposure time of hydrogen shown in Fig c. (c) Real-time amperometric hydrogen sensor response in two RTILs, applying a constant potential of $+0.4 \mathrm{~V}$ vs ferrocene/ferrocenium. Hydrogen is repeatedly being introduced to the sensor with sampling time of 20 seconds and then removed by purging with nitrogen background gas for each measurement. All figures are reproduced from [26] with permission from The Royal Society of Chemistry. Here, the nomenclature $[\mathrm{Bmpy}]^{+}=\left[\mathrm{C}_{4} \mathrm{mpyrr}\right]^{+}$and $[\mathrm{Bmim}]^{+}=\left[\mathrm{C}_{4} \mathrm{mim}\right]^{+}$.

\section{Planar or printed electrode devices}

An alternative design to the Clark-type sensor is one that allows partitioning of the gas into the liquid phase,

followed by diffusion of the gas towards the electrode surface for detection, as demonstrated in Figure $1 \mathrm{f}$ (left). Various low-cost devices such as screen-printed electrodes (SPEs), thin-film electrodes and 
interdigitated electrodes have been developed by companies and are now widely available for academic research. RTILs are ideal for use with planar electrode devices, since volumes as small as a few microlitres can be employed without any issue of solvent evaporation. The choice of electrode material is important; there are very few studies with carbon SPEs due to large capacitive currents observed with RTIL solvents [44]. However, a home-made low-cost screen-printed graphite electrode was successfully employed for low-cost oxygen detection [29], with different ionic liquids showing varying responses, and some showing degradation of the electrode after long-term biasing. Binding materials from DropSens screen-printed $\mathrm{Pt}$ electrodes were found to facilitate proton-abstraction by superoxide from imidazolium RTILs [30], giving rise to an irreversible oxygen reduction peak and vast potential shifting between scans. Various electrode pre-treatment methods were attempted, and it was found that mechanical polishing of the SPE could improve the long-term response, but also successfully regenerate a "fouled" electrode [30].

Electrode materials made purely of metals give much more stable responses compared to screen-printed electrodes that are complicated by the presence of binders. Thin-film electrodes (TFEs), microarray thinfilm electrodes (MATFEs), and interdigitated electrodes (IDEs) have all been explored as new sensor surfaces in RTILs for the detection of ammonia [31, 32] and oxygen [33] gases. The design of a commercially-available MATFE form MicruX is shown in Figure 3a; the WE consists of 90 recessed microdisk electrodes, in close proximity with the RE and CE. This electrode design was used successfully with $2 \mu \mathrm{L}$ of RTIL for ammonia detection with extremely stable and reproducible results, and it produced the lowest limit of detection reported for ammonia in pure RTILs reported to date (20 ppb) due to the high current density possible from the microarray design. A platinum interdigitated electrode was used for enhanced oxygen detection, taking advantage of the electrochemical reversibility of the oxygen reduction reaction [33]. An innovative approach involved producing a product (superoxide) at WE1, which was reoxidised at WE2. This gave enhanced current signals and potentially provides selectivity over gases with irreversible redox chemistry [33].

\section{Improving Response Times}

The use of a droplet of RTIL can cause slow response times to changing gas concentrations due to the slow partitioning and diffusion time in RTILs. Therefore, several attempts have been made to facilitate the diffusion of gas analytes in RTILs. A highly efficient strategy involves the formation of thin layers of RTILs on microchannel arrays. Transport of the analyte gas (oxygen) to the electrode was aided by the inclusion of magnetic nanostirrers into the RTIL with faster response times and improved current density [38]. This electrode design was later used (but without the nanostirrers) to detect the toxic gases ammonia and hydrogen chloride [39] in RTILs, with stable and fast responses at low ppm concentrations, well below the long-term exposure limits. Planar devices have also been used with a porous PTFE substrate [1, 27, 28], onto which metallic electrodes (gold or platinum) were microfabricated into a small area. This design combines the benefits of fast response times, miniaturisation, low-cost, and small volumes of RTILs. The 
authors successfully detected multiple pollutants with better sensitivity, linearity, and repeatability compared to the Clark-cell predecessor [1,27], with response times as low as $4 \mathrm{~s}$ for oxygen [28]. These devices show great promise for deployment as wearable devices for real-time point-of-exposure gas monitoring.

\section{Mechanical Stabilisation of the Electrolyte}

Using planar devices with droplets of ionic liquids introduces the issue of solvent flow or leakage when the sensor is tilted, shaken or agitated. As a result, various attempts have been made to mechanically stabilise the RTIL solvent on the electrode with the goal to create "spill-less" devices. One method is to mix RTILs with polymers to create gelled materials that do not flow [45]. Not only does the polymer aid in stabilisation of the RTIL on the surface, it also allows the possibility to spin-coat thin layers onto planar substrates without the formation of discontinuous droplets that occurs with many pure RTILs [16]. This reduces response times due to the small diffusion distance to the electrode surface. For example, a drop-casted film (50:50 mass ratio) of $\left[\mathrm{C}_{2} \mathrm{mim}\right]\left[\mathrm{NTf}_{2}\right]$ and poly(methyl methacrylate) (PMMA) was used with a microarray thin-film electrode device for oxygen detection [34]. Lower currents were observed due to the viscous gelpolymer mixture, however, better long-term behaviour even at very high concentrations of oxygen ( $>60 \%$ vol.) was achieved, where traditional sensors often struggle to function. In addition to the improved sensing performance, by replacing 50 mass \% of the RTIL electrolyte with a cheaper common polymer (PMMA) results in a significant for cost reduction for materials in the sensor device. Zhang et al. [36] proposed an oxygen sensor using a "double layer ionic liquid film", created by combining a PMMA/[C $4 \mathrm{mim}]\left[\mathrm{BF}_{4}\right]$ film with a PVDF/[C $\left.\mathrm{C}_{4} \mathrm{mim}\right]\left[\mathrm{BF}_{4}\right]$ film. Good linearity was observed between current and oxygen concentration and the authors suggested that the synergism of different polymers also enhances the electrochemical oxygen sensor performance.

An alternative and highly innovative approach for a "spill-less" gas sensor was proposed by Gondosiswanto et al. [37], who used thiol-functionalised ionic liquids bound to a gold electrode surface through sulfur-gold interactions to produce thin-layer microchannel arrays. The electrode was tested for its response to oxygen reduction in various orientations (upright, upside down, sideways) and showed good stability and reproducibility, combined with fast response times due to the thin layer of RTIL employed.

\section{Electrode Surface Modification for Enhanced Analytical Responses}

In addition to changing the ionic liquid material, the underlying electrode surface can also be altered to provide enhanced functionality. This has been exploited, for example, in the formation of highly porous electrodes using a polystyrene sphere template [42], where the sensitivity towards hydrogen oxidation was greatly increased by the presence of the pores to which the gas had a strong affinity. A potential application is a 'leak-detector' for low concentrations of hydrogen gas [42], that could trigger an alarm at concentrations well below explosive levels ( $<4 \%$ vol. $\mathrm{H}_{2}$ in air). 
Further modifications to electrode designs were investigated for enhanced sensitivity towards gases. For example, MATFEs were modified with 3D 'cauliflower' [40] and dendritic platinum growths [41] (see Figure $3 b$ ) to produce arrays of 90 high-surface area electrodes that had massively enhanced surface areas compared to the unmodified microarrays. Increased current density was observed for ammonia oxidation [40] due to the improved diffusion characteristics that come about by filling of the pores (see Figure 3c). The highest sensitivity for oxygen reduction (Figure 3d) was achieved when dendritic growths were grown from the pores in the presence of a structure directing agent, lead acetate, during a two-step Pt deposition process [41]. In both cases, less than $3 \mu \mathrm{L}$ of RTIL was required for the gas sensing experiments. These studies demonstrate that low-cost commercially available devices can be successfully modified for improved analytical responses, with 9 times and 16 times sensitivity enhancements for ammonia [40] and oxygen [41], respectively.

(a)

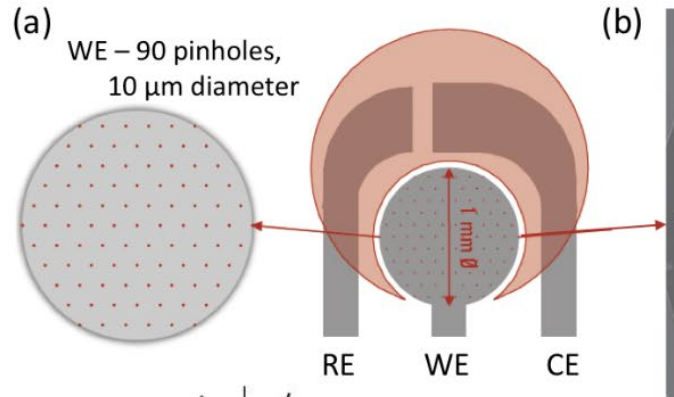

(c)

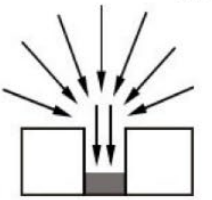

Recessed microdisk Radial and linear diffusion

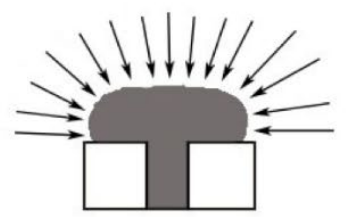

Modified microdisk Enhanced radial diffusion (b)
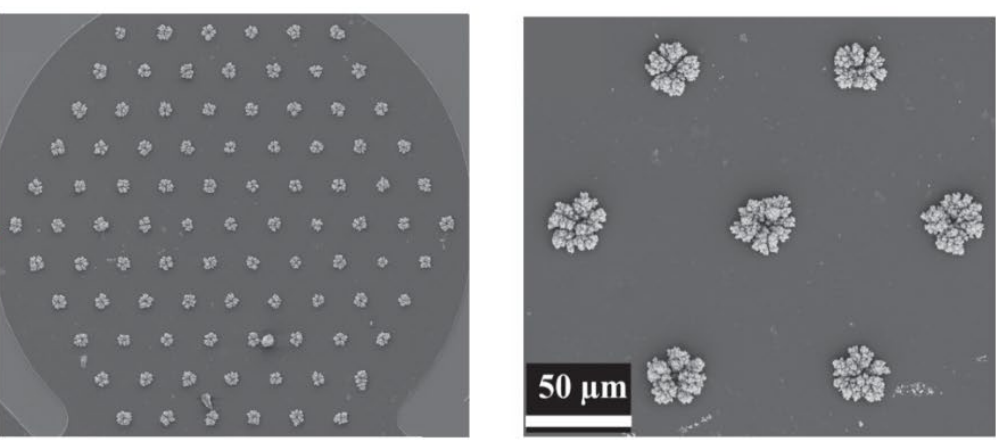

(d)

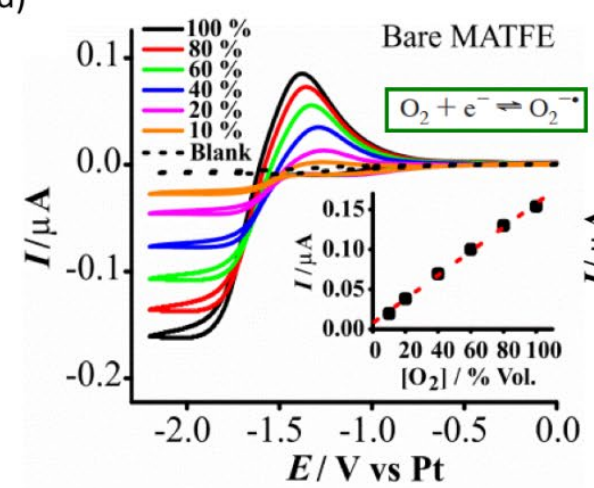

Figure 3. (a) Schematic of a micro-array thin film electrode (MATFE) from MicruX (www.micruxfluidic.com) with 90 recessed electrodes, each $10 \mu \mathrm{m}$ in diameter, in close proximity to the counter and reference electrodes. (b) SEM images of a MATFE modified with Pt 3D dendritic structures by deposition from a Pt plating bath solution ( $20 \mathrm{mM} \mathrm{H}_{2} \mathrm{PtCl}_{6} / 0.5 \mathrm{M} \mathrm{H}_{2} \mathrm{SO}_{4}$ in the presence of $2 \mathrm{mM}$ lead acetate, one-step holding the potential at $-0.2 \mathrm{~V} \mathrm{vs} \mathrm{Ag} / \mathrm{AgCl}$ for $300 \mathrm{~s}$ ). (c) Expected diffusion patterns to the unmodified MATFE with a recessed microdisk, compared to a modified macrodisk with 3D Pt structures. (d) Cyclic voltammetry for the reduction of $10-100 \%$ vol. $\mathrm{O}_{2}$ on the unmodified MATFE and (inset) the corresponding calibration graph. Figure to the right is a comparison of $\mathrm{O}_{2}$ calibration graphs on MATFEs modified with the different structures formed by varying the deposition parameters (see [41] for full details), compared to the unmodified array (grey squares). Figures b and $\mathrm{d}$ are modified from [41].

\section{Summary and Perspectives}

The variety of studies over the last few years demonstrate the continued interest in RTIL-based AGSs. Since their initial suggestion as membrane-free electrolytes ca. 15 years ago, many studies have been performed with these materials as electrolytes, yet it is surprising that there are no commercially available AGS devices adopting RTILs. Despite their obvious advantages of low-volatility, high thermal stability, wide electrochemical windows, and good solvating properties, the additional challenges of RTILs that come 
about by removal of the membrane have yet to be overcome. The most obvious issue is the sensitivity of RTILs to water [46, 47], since water is known to change RTIL viscosity and influence reaction outcomes; this requires more detailed understanding of the effect of ambient moisture and air on reaction mechanisms and current responses. Although self-calibrating "intelligent sensors" can adjust to changes in the sensing environment, this may not be possible if the outcome of the electrochemical reaction is altered. Innovative ways to address this issue could be the use of more hydrophobic materials - either the RTIL itself, or for example, by mixing with a polymer possessing highly hydrophobic functionalities. The choice of RTIL is already known to be important - e.g. both imidiazolium [48] and even phosphonium [49] cations are known to undergo proton abstraction in the presence of strong bases such as superoxide.

It has been demonstrated that RTILs can be successfully employed with traditional Clark-type cells while retaining fast response times, but the drawback to this design is the use of relatively large $(\sim 150 \mu \mathrm{L})$ volumes of solvent and complicated sensor design, adding to the overall cost. Miniaturised planar electrodes with very small volumes (e.g. 1-5 $\mu \mathrm{L}$ ) can reduce cost - both in terms of the sensor device manufacturing and electrolyte amount needed; while response times can be improved by employing thin electrolyte layers. However, the build-up of electrogenerated products may be significant, especially if very thin layers are employed. In this case, the use of innovative techniques, such as double potential step chronoamperometry [28] to selected reactions could effectively extend the sensor lifetime by reducing the build-up of undesired products.

Another consideration for RTIL-based AGSs is the common use of a quasi-reference electrode, which has been shown to shift the potential of a bare Pt-TFE surface by $\sim 200 \mathrm{mV}$ and $\sim 800 \mathrm{mV}$ upon the introduction of $20 \%$ vol. $\mathrm{O}_{2}$ and $1 \% \mathrm{H}_{2}$ gas, respectively [50]. With such large potential shifts occurring when gas is introduced, the development of a reference electrode surface insensitive to atmospheric changes would be highly desired. A novel reference electrode was recently developed, comprising of a Pt-TFE coated with a common battery material (lithium iron phosphate) [50] that avoided the large reference potential shifts seen at the bare Pt surface, but the behaviour of this material in the presence of strong bases or dissolved water is still unknown.

Overall, it is clear that RTILs show tremendous promise as electrolytes in AGSs, and the tunability in their structure allows for tailoring the response towards different intended applications. Both sensitivity and selectivity could be improved by the judicious choice of RTIL ions, electrode materials, and electrochemical methods. It would be exciting to see RTIL-based gas sensors become widely available as low-cost, mass-producible devices available to everyone (e.g. to monitor air quality) in the same way as the highly successful blood glucose sensor.

\section{Declaration of Interest}

None 


\section{Acknowledgements}

DSS thanks Dr Junqiao Lee for proof-reading. This work was supported by the Australian Research Council (Future Fellowship grant number: FT170100315).
Abbreviations
$\left[\mathrm{C}_{2} \operatorname{mim}\right]\left[\mathrm{PF}_{6}\right]$
1-ethyl-3-methylimidazolium hexafluorophosphate
$\left[\mathrm{C}_{2} \operatorname{mim}\right]\left[\mathrm{NTf}_{2}\right]$
1-ethyl-3-methylimidazolium bis(trifluoromethylsulfonyl)imide
$\left[\mathrm{C}_{4} \mathrm{mpyrr}\right]\left[\mathrm{NTf}_{2}\right]$
1-butyl-1-methylpyrrolidinium bis(trifluoromethylsulfonyl)imide
$\left[\mathrm{N}_{8,2,2,2]\left[\mathrm{NTf}_{2}\right]}\right.$
triethyloctylammonium bis(trifluoromethylsulfonyl)imide
$\left[\mathrm{C}_{4} \mathrm{mim}\right][\mathrm{Cl}]$
1-butyl-3-methylimidazolium tetrafluoroborate
$\left[\mathrm{C}_{4} \mathrm{mim}\right]\left[\mathrm{BF}_{4}\right]$
1-butyl-3-methylimidazolium tetrafluoroborate
$\left[\mathrm{C}_{4} \mathrm{mim}\right]\left[\mathrm{PF}_{6}\right]$
1-butyl-3-methylimidazolium hexafluorophosphate
$\left[\mathrm{C}_{4} \mathrm{mim}\right]\left[\mathrm{NTf}_{2}\right]$
1-butyl-3-methylimidazolium bis(trifluoromethylsulfonyl)imide
$\left[\mathrm{C}_{5} \mathrm{mim}\right]\left[\mathrm{PF}_{6}\right]$
1-pentyl-3-methylimidazolium hexafluorophosphate
[MOMIM] $\left[\mathrm{PF}_{6}\right]$
1-[8-mercaptooctyl]-3-methylimidazolium hexafluorophosphate
$\mathrm{Ag} / \mathrm{AgCl}$
Silver/Silver chloride
AGS
Amperometric gas sensor
CA
Chronoamperometry
$\mathrm{CE}$
Counter electrode
$\mathrm{CV}$
Cyclic voltammetry
$\mathrm{GC}$
Glassy carbon
GPM
Gas-permeable membrane
IL
Ionic liquid
LOD
Limit of detection
LSV
Linear sweep voltammetry
LTCA
Long-term chronoamperometry
$\mathrm{O}$
O-ring
$\mathrm{RE}$
Reference electrode
RTIL
Room temperature ionic liquid
PMMA
Poly(methyl methacrylate)
ppm
Parts-per-million
PTFE
Polytetrafluoroethylene
PVDF
Polyvinylidene fluoride
rpm
Revolutions per minute
SEM
Scanning electron microscopy
SPE
Screen-printed electrode
SWV
Square wave voltammetry
TFE
Thin-film electrode
VOC
Volatile organic compound
WE
Working electrode 


\section{References and recommended reading}

Papers of particular interest, published within the period of review, have been highlighted as:

- Paper of special interest $\quad \bullet$ Paper of outstanding interest.

[1] H. Wan, H. Yin, L. Lin, X. Zeng, A.J. Mason, Miniaturized planar room temperature ionic liquid electrochemical gas sensor for rapid multiple gas pollutants monitoring, Sens. Act. B, 255 (2018) 638-646. [2] L. Xiong, R.G. Compton, Amperometric Gas detection: A Review, Int. J. Electrochem. Sci., 9 (2014) $7152-$ 7181.

[3] L.C. Clark JR., R. Wold, D. Granger, Z. Taylor, Continuous Recording of Blood Oxygen Tensions by Polarography, J. Appl. Physiol., 6 (1953) 189-193.

[4] J.R. Stetter, J. Li, Amperometric Gas Sensors - A Review, Chem. Rev., 108 (2008) 352-366.

[5] H.A. Yu, D.A. DeTata, S.W. Lewis, D.S. Silvester, Recent developments in the electrochemical detection of explosives: Towards field-deployable devices for forensic science, Trends Anal. Chem., 97 (2017) 374384.

[6] X.Y. Mu, Z. Wang, M. Guo, X.Q. Zeng, A.J. Mason, Fabrication of a Miniaturized Room Temperature Ionic Liquid Gas Sensor for Human Health and Safety Monitoring, Biomed Circ Syst C, (2012) 140-143.

[7] T. Welton, Room-Temperature Ionic Liquids. Solvents for Synthesis and Catalysis, Chem. Rev., 99 (1999) 2071-2083.

[8] L.E. Barrosse-Antle, A.M. Bond, R.G. Compton, A.M. O'Mahony, E.I. Rogers, D.S. Silvester, Voltammetry in Room Temperature Ionic Liquids: Comparisons and Contrasts with Conventional Electrochemical Solvents, Chem. Asian J., 5 (2010) 202-230.

[9] M.C. Buzzeo, R.G. Evans, R.G. Compton, Non-Haloaluminate Room-Temperature lonic Liquids in Electrochemistry-A Review, Phys. Chem. Chem. Phys., 5 (2004) 1106-1120.

[10] M.J.A. Shiddiky, A.A.J. Torriero, Application of ionic liquids in electrochemical sensing systems, Biosens. Bioelectron., 26 (2011) 1775-1787.

[11] N.V. Shvedene, D.V. Chernyshov, I.V. Pletnev, Ionic Liquids in Electrochemical Sensors, Russ. J. General Chem., 52 (2008) 80-91.

[12] D.S. Silvester, Recent advances in the use of ionic liquids for electrochemical sensing, Analyst, 136 (2011) 4871-4882.

[13] D.S. Silvester, L. Aldous, Chapter 10: Electrochemical detection using ionic liquids, in: D.W.M. Arrigan (Ed.) Electrochemical Strategies in Detection Science, RSC, Cambridge, UK, 2016.

[14] W. Wei, A. Ivaska, Applications of ionic liquids in electrochemical sensors, Anal. Chim. Acta, 607 (2008) 126-135.

[15] M.C. Buzzeo, C. Hardacre, R.G. Compton, Use of Room Temperature Ionic Liquids in Gas Sensor Design, Anal. Chem., 76 (2004) 4583-4588.

[16] X.-J. Huang, L. Aldous, A.M. O'Mahony, F.J. del Campo, R.G. Compton, Toward Membrane-Free Amperometric Gas Sensors: A Microelectrode Array Approach, Anal. Chem., 82 (2010) 5238-5245.

[17] E.I. Rogers, A.M. O'Mahony, L. Aldous, R.G. Compton, Amperometric Gas Detection Using Room Temperature Ionic Liquid Solvents, Ecs Transactions, 33 (2010) 473-502.

[18] A. Khan, C.A. Gunawan, C. Zhao, Oxygen Reduction Reaction in Ionic Liquids: Fundamentals and Applications in Energy and Sensors, ACS Sustainable Chem. Eng., 5 (2017) 3698-3715.

[19] A. Rehman, X. Zeng, Methods and approaches of utilizing ionic liquids as gas sensing materials, RSC Adv., 5 (2015) 58371-58392.

[20] C. Zhao, C.A. Gunawan, M. Ge, R. Gondosiswanto, L. Aldous, Recent advances in ionic liquid-based gas sensors, in: Analytical Applications of lonic Liquids, World Scientific Publishing Co. Pty Ltd, 2016, pp. 287-338. 
- Book chapter on various applications of ionic liquid-based gas sensors. The review covers the years 2011-2015, so can be thought of as a predecessor to this review.

[21] J. Gębicki, A. Kloskowski, W. Chrzanowski, P. Stepnowski, J. Namiesnik, Application of lonic Liquids in Amperometric Gas Sensors, Crit. Rev. Anal. Chem., 46 (2016) 122-138.

-. An excellent technical review article that discusses the inner workings of AGSs including the aspects contributing to signal generation. Covers work in the area up to 2015.

[22] X. Chi, Y. Tang, X. Zeng, Electrode Reactions Coupled with Chemical Reactions of Oxygen, Water and Acetaldehyde in an lonic Liquid: New Approaches for Sensing Volatile Organic Compounds, Electrochim. Acta, 216 (2016) 171-180.

[23] Y. Tang, X. Zeng, Electrochemical oxidation of hydrogen in Bis (trifluoromethylsulfonyl) imide ionic liquids under anaerobic and aerobic conditions, J. Phys Chem. C, 120 (2016) 23542-23551.

[24] E. Jayanthi, N. Murugesan, A.S. Suneesh, C. Ramesh, S. Anthonysamy, Sensing Behavior of Room Temperature Amperometric H2 Sensor with Pd Electrodeposited from Ionic Liquid Electrolyte as Sensing Electrode, J. Electrochem. Soc., 164 (2017) H5210-H5217.

[25] L. Lin, X. Zeng, Toward continuous amperometric gas sensing in ionic liquids: rationalization of signal drift nature and calibration methods, Anal. Bioanal. Chem., 410 (2018) 4587-4596.

[26] Y. Tang, J. He, X. Gao, T. Yang, X. Zeng, Continuous Amperometric Hydrogen Gas Sensing in Ionic Liquids, Analyst, 143 (2018) 4136-4146.

- Demonstration of long-term sensing of a hydrogen at low percent concentrations, with many useful discussions on the challenges and requirements for amperometric gas sensors.

[27] H. Yin, H. Wan, L. Lin, X. Zeng, A.J. Mason, Miniaturized planar RTIL-based eletrochemical gas sensor for real-time point-of-exposure monitoring, IEEE Healthcare Innovation Point-Of-Care Technologies Conference, (2016) 85-88.

[28] H. Wan, H. Yin, A.J. Mason, Rapid measurement of room temperature ionic liquid electrochemical gas sensor using transient double potential amperometry, Sens. Act. B, 242 (2017) 658-666.

[29] J. Lee, G. Hussain, C.E. Banks, D. Silvester, S., Screen-Printed Graphite Electrodes as Low-Cost Devices for Oxygen Gas Detection in Room-Temperature lonic Liquids, Sensors, 17 (2017) 2734.

[30] J. Lee, D.W.M. Arrigan, D.S. Silvester, Achievement of Prolonged Oxygen Detection in RoomTemperature Ionic Liquids on Mechanically Polished Platinum Screen-Printed Electrodes, Anal. Chem., 88 (2016) 5104-5111.

- Demonstrates that cheap screen-printed devices can be significantly improved by treatment of the electrode surface before and after sensing.

[31] G. Hussain, D.S. Silvester, Detection of sub-ppm Concentrations of Ammonia in an Ionic Liquid: Enhanced Current Density Using 'Filled' Recessed Microarrays, Anal. Chem., 88 (2016) 12453-12460.

- The lowest detection limit to date (20 parts per billion) for ammonia was reported in a neat RTIL.

[32] G. Hussain, D. Silvester, S., Comparison of Voltammetric Techniques for Ammonia Sensing in Ionic Liquids, Electroanalysis, 30 (2018) 75-83.

[33] R. Gondosiswanto, D.B. Hibbert, Y. Fang, C. Zhao, Redox Recycling Amplification Using an Interdigitated Microelectrode Array for Ionic Liquid-Based Oxygen Sensors, Anal. Chem., 90 (2018) 39503957.

[34] J. Lee, D.S. Silvester, Low-cost microarray thin-film electrodes with ionic liquid gel-polymer electrolytes for miniaturised oxygen sensing, Analyst, 141 (2016) 3705-3713.

- A gel-polymer with microarrays showed the benefits of improved current density and current enhancements, while showing less build-up of electrogenerated products compared to a pure RTIL.

[35] Y. Liu, J. Liu, Q. Liu, H. Zhang, Z. Li, X. Jing, Y. Yuan, H. Zhang, P. Liu, J. Wang, lonic liquids combined with Pt-modified ordered mesoporous carbonsas electrolytes for the oxygen sensing, Sens. Act. B, 254 (2018) 490-501. 
[36] H. Zhang, J. Liu, Q. Liu, R. Chen, H. Zhang, J. Yu, D. Song, X. Jing, M. Zhang, J. Wang, Electrochemical Oxygen Sensor Based on the Interaction of

Double-Layer Ionic Liquid Film (DLILF), J. Electrochem. Soc., 165 (2018) B779-B786.

[37] R. Gondosiswanto, C.A. Gunawan, D.B. Hibbert, J.B. Harper, C. Zhao, Microcontact Printing of ThiolFunctionalized Ionic Liquid Microarrays for "Membrane-less" and "Spill-less" Gas Sensors, ACS Appl. Mater. Interfaces, 8 (2016) 31368-31374.

- Innovative functionalisation of the ionic liquid structure allowed mechanical stabilisation on a gold electrode surface, with a spill-less sensor obtained.

[38] R. Gondosiswanto, D.B. Hibbert, Y. Fang, C. Zhao, lonic Liquid Microstrips Impregnated with Magnetic Nanostirrers for Sensitive Gas Sensors, ACS Appl. Mater. Interfaces, 9 (2017) 43377-43385.

[39] M. Ge, G. Hussain, D.B. Hibbert, D.S. Silvester, C. Zhao, Ionic Liquid-based Microchannels for Highly Sensitive and Fast Amperometric Detection of Toxic Gases, Electroanalysis, 31, (2019) 66-74.

[40] G. Hussain, L. Aldous, D.S. Silvester, Preparation of Platinum-based 'Cauliflower Microarrays' for Enhanced Gas Sensing, Anal. Chim. Acta, 1048 (2019) 12-21.

[41] G. Hussain, A.P. O'Mullane, D. Silvester, S., Modification of Microelectrode Arrays with High Surface Area Dendritic Platinum 3D Structures: Enhanced Sensitivity for Oxygen Detection in lonic Liquids, Nanomaterials, 8 (2018) 735.

- This work shows that commercially-available planar devices can be successfully enhanced with 3D materials to improve sensitivity towards gas detection.

[42] G. Hussain, M.V. Sofianos, J. Lee, C. Gibson, C.E. Buckley, D. Silvester, S., Macroporous platinum electrodes for hydrogen oxidation in ionic liquids, Electrochem. Commun., 86 (2018) $43-47$.

[43] G. Hussain, M. Ge, C. Zhao, D. Silvester, S., Fast Responding Hydrogen Gas Sensors using Platinum Nanoparticle Modified Microchannels and lonic Liquids, submitted.

[44] K. Murugappan, J. Lee, D.S. Silvester, Comparative study of screen printed electrodes for ammonia gas sensing in ionic liquids, Electrochem. Commun., 13 (2011) 1435-1438.

[45] J. Lee, G. Du Plessis, D.W.M. Arrigan, D.S. Silvester, Towards improving the robustness of electrochemical gas sensors: impact of PMMA addition on the sensing of oxygen in an ionic liquid, Anal. Methods, 7 (2015) 7327-7335.

[46] A.M. O'Mahony, D.S. Silvester, L. Aldous, C. Hardacre, R.G. Compton, Effect of Water on the Electrochemical Window and Potential Limits of Room-Temperature lonic Liquids, J. Chem. Eng. Data, 53 (2008) 2884-2891.

[47] J. Lee, D. Silvester, S., Electrochemical Detection of Explosive Compounds in an Ionic Liquid in Mixed Environments: Influence of Oxygen, Moisture, and Other Nitroaromatics on the Sensing Response, Aust. J. Chem., 72, (2019) 122-129.

[48] J.T. Frith, A.E. Russell, N. Garcia-Araez, J.R. Owen, An in-situ Raman study of the oxygen reduction reaction in ionic liquids, Electrochem. Commun., 46 (2014) 33-35.

[49] P. Li, E.O. Barnes, C. Hardacre, R.G. Compton, Microelectrode Voltammetry of Dioxygen Reduction in a Phosphonium Cation-Based Room-Temperature Ionic Liquid: Quantitative Studies, J. Phys Chem. C, 119 (2015) 2716-2726.

[50] J. Wandt, J. Lee, D.W.M. Arrigan, D.S. Silvester, A lithium iron phosphate reference electrode for ionic liquid electrolytes, Electrochem. Commun., 93 (2018) 148-151. 